\title{
Selection in the Finnhorse, a native all-around horse breed
}

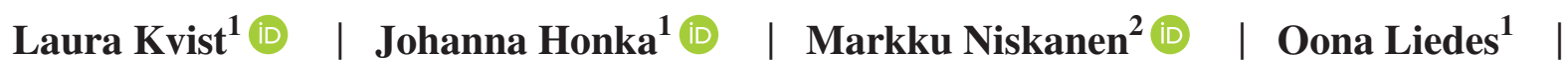 \\ Jouni Aspi ${ }^{1}$ (D)
}

${ }^{1}$ Department of Ecology and Genetics, University of Oulu, Oulu, Finland

${ }^{2}$ Research Unit of History, Culture and Communications, University of Oulu, Oulu, Finland

\section{Correspondence}

Laura Kvist, Department of Ecology and Genetics, University of Oulu, POB 8000, 90014 Oulu, Finland.

Email: laura.kvist@oulu.fi

\section{Funding information}

Suomen Kulttuurirahasto

\begin{abstract}
Selection by breeders modifies the morphology, behaviour and performance of domesticated species. Here, we examined signs of selection in Finnhorse, the only native horse breed in Finland. We first searched divergent genomic regions between Finnhorses and other breeds, as well as between different breeding sections of the Finnhorse with data from Illumina Equine SNP70 BeadChip, and then studied several of the detected regions in more detail. We found altogether 35 common outlier SNPs between Finnhorses and other breeds using two different selection tests. Many of the SNPs were located close to genes affecting coat colour, performance, size, sugar metabolism, immune response and olfaction. We selected genes affecting coat colour (KIT, MITF, PMEL), performance (MSTN) and locomotion (DMRT3) for a more detailed examination. In addition, we looked for, and found, associations with height at withers and SNPs located close to gene LCORL. Among the four breeding sections of Finnhorses (harness trotters, riding horses, draught horses and pony-sized horses), a single SNP located close to the DMRT3 gene was significantly differentiated and only between harness trotters and pony-sized horses.
\end{abstract}

\section{K E Y W O R D S}

coat colour, locomotion, outlier SNP, size at withers, whole-genome analysis

\section{1 | INTRODUCTION}

Domestication fundamentally changes the behaviour, morphology, physiology and performance of animal species through selective breeding-breeders' decisions of which individuals will be allowed to reproduce. This artificial selection is often directional, decreasing the amount of genetic diversity within breeds. Genetic diversity can decrease also because of fixation of breed-specific traits through inbreeding, genetic drift and founder effect (Frantz et al., 2020; Mignon-Grasteau et al., 2005). On the other hand, different breeds of a given domesticated species can vary considerably due to artificial diversifying selection. Examples of large phenotypic differences between breeds and between wild and domesticated animals are the huge variations in coat colour (Cieslak et al., 2011) or body size (e.g., in dogs, Canis lupus familiaris; Beale \& Ostrander, 2012), which are common in domesticated species, but often show limited variation within breeds. Thus, captive breeding may on the one hand decrease overall phenotypic and genetic variation and on the other hand increase it for certain traits.

Horses (Equus caballus) have been selectively bred for centuries, especially for transportation, agriculture and warfare, nowadays mainly for leisure and sports activities.

This is an open access article under the terms of the Creative Commons Attribution License, which permits use, distribution and reproduction in any medium, provided the original 
Schubert et al. (2014) identified altogether 125 genomic regions, which have potentially been affected by the domestication process in the horse. They classified these regions into two groups, of which the first consisted of genes involved in muscular and limb development, articular junctions and the cardiac system (physiological adaptations), and the second consisted of genes with cognitive functions (tameness). Several of the genomic changes accompanying domestication have indeed been related to forelimb robustness, performance, gaits, cognitive skills and behaviour, but also to coat colour, many of which support the "neural crest hypothesis for domestication" (Librado et al., 2017; Ludwig et al., 2009; Petersen, Mickelson, Rendahl, et al., 2013); that is, development of number of these traits is linked to neural crest cells (Wilkins et al., 2014). Much research has recently focused on these traits in horses, especially on genes affecting colour, gait patterns and performance (reviewed, e.g., in Raudsepp et al., 2019). Connected with the "neural crest hypothesis of domestication," mutations in genes affecting tissues originating from the neural crest cells have been found also to cause several diseases. Such diseases are, for example, the lethal white syndrome and stationary night blindness in horses (Metallinos et al., 1998; Raudsepp et al., 2019), which affect also coat colour. In general, genetic load in horses has increased and diversity decreased especially during the last couple of hundreds of years, due to modern breeding practices (Fages et al., 2019; Raudsepp et al., 2019).

Finnhorse as a breed was officially founded with the establishment of the studbook in 1907. We refer native horses of Finland predating this year as Finnish horses. These Finnish horses formed three main types in the early 20th century: (a) heavy horses used in agriculture; (b) lightly built and "leggy" horses used in harness racing; and (c) relatively light, pony-sized horses, in addition to local landraces. The breed was strongly selected for colour and size in the early years. Only horses representing the heavy type were accepted in the studbook between 1907 and 1924, because agriculture and forestry required draft-type horses. However, as trotting speed was desired in addition to weight pulling, most stallions represented a light-draft phenotype. Accepted stallions had to be at least $148 \mathrm{~cm}$ tall at the withers (Ojala et al., 2007; Peltonen, 2014). There was also intense selection for colour, with chestnuts strongly favoured, and "foreign" colours (white, grey, palomino and piebald) not accepted. In 1871 , only about $23 \%$ of the Finnish horses were chestnuts, contrary to 1920 , during which over $85 \%$ of the Finnhorses accepted to the studbook were chestnuts (Perttunen, 2007).

Due to the Finnish military's need for riding horses, the Finnhorse studbook was divided into two sections in 1924, heavier draft-type horses and light-type riding horses. Light horses with phenotypic traits of warmblood riding horses (e.g., an open throatlatch, a longer neck), excluded from the studbook since 1907, were thus now accepted. However, favouring of draft-type phenotypes since 1907 had already largely depleted suitable breeding material for light horses (Ojala et al., 2007), and in the late 1940s, it was actually noted that the overall suitability of the Finnhorse for riding had deteriorated over time (Ojala, 1997, 2007). The lighttype horse section that included also Finnhorses competing in harness trotting was renamed as the universal horse section in 1935 and was replaced by a trotting horse section in 1965 (Ojala, 1997; Ojala et al., 2007).

Since 1971, Finnhorses have been bred in four breeding sections: harness trotters, riding horses, pony-sized horses and draught horses. Horses of each breeding section need to fill section-specific criteria for acceptance to a breeding section. This has brought additional selection for traits specific to these breeding sections (e.g., performance, gait, size and conformation; Ojala, 2007). Registered Finnhorses form a common gene pool, from which new horses can be accepted to a breeding section after individual evaluation. Thus, a given horse can belong to several breeding sections and offspring do not automatically belong to the breeding section(s) of their parents (The Finnish Trotting and Breeding Association, 2017). Most Finnhorses are not evaluated and do not belong to any of the breeding sections. This likely leads to a quite weak effect of selection within the breeding sections. The studbook has been closed for 110 years and provides pedigrees and much of other information of all Finnhorses (The Finnish Trotting and Breeding Association, 2017).

Recent analyses of genomic SNPs and mitochondrial DNA in Finnhorses showed that mitochondrial genetic diversity and female effective populations sizes are high (Kvist et al., 2019), which is common for all horse breeds (e.g., Jansen et al., 2002; Raudsepp et al., 2019). On the other hand, effective population size $\left(\mathrm{N}_{\mathrm{e}}\right)$ from the nuclear SNP data was just about 50 for each of the breeding sections and for the breed as a whole (Kvist et al., 2019). For comparison, $\mathrm{N}_{\mathrm{e}}$ calculated from genome-wide SNP data from close to 40 breeds varied between 143 and 751 (Petersen, Mickelson, Cothran, et al., 2013), and in several native breeds with small populations, $\mathrm{N}_{\mathrm{e}}$ was considerably smaller (e.g., 41 in South Korean Jeju horses; Do et al., 2014, 39 in Italian Bardigiano horses; Ablondi et al., 2020, and 40-85 in several native Polish breeds; Jasielczuk et al., 2020). Based on inbreeding coefficients and number of runs of homozygosity (ROHs), inbreeding has not been very high compared with other breeds, but ROHs were on average longer than in several other breeds (Kvist et al., 2019). There are not many studies of specific phenotypic or genotypic traits in Finnhorses. However, a few reports based on pedigree analyses and information from studbook have shown that size is positively correlated with racing performance and has a high heritability, whereas correlation of body conformation with racing traits is low and has a low heritability (Suontama et al., 2009, 2013). Of the specific genotyped traits, the DMRT3 (Doublesex And Mab-3 Related Transcription Factor 3) gene alleles have been 
found to affect speed in trotting horses and quality of gaits in riding horses (Jäderkvist et al., 2015).

Here, our aim was to study signs of selection in Finnhorses to obtain more information about genes and genomic regions that have been affected by human-mediated selection. We explored whether there are sites of genomic differentiation between Finnhorses and other breeds in general by first screening for candidate loci under selection by comparing SNP chip data of Finnhorses with other breeds. We also searched for signs of selection between the breeding sections (harness trotters, riding horses, pony-sized horses and draught horses) of the Finnhorse. Based on the results of the screenings, we then studied a selected set of loci previously connected to coat colour, performance, locomotion and height at withers to identify candidate loci for a set of specific traits.

\section{MATERIALS AND METHODS}

\section{1 | Samples, questionnaires and SNP data}

We analysed altogether 985 horse samples that were previously included in the study by Kvist et al., (2019). These samples included 846 registered Finnhorses of which 205 were registered in specific breeding sections. Of the horses registered in breeding sections, 67 were harness trotters, 79 riding horses, 30 draught horses and 51 pony-sized horses. Altogether, 16 of these horses were concurrently registered in two breeding sections (three in both trotter and riding, three in riding and draught, five in riding and pony-sized, one in draught and pony-sized and four in trotter and draught). Additional 139 horses of 27 other breeds (and one of unknown breed from Estonia), including six crossbreds, were sampled (Kvist et al., 2019; Table 1). Samples were obtained either from horse owners (hair samples from mane or tail, $N=954$ ) or from an equine veterinary hospital (blood samples, with the permission from the owners, $N=31$ ). DNA was extracted from these samples as in Kvist et al. (2019).

The horse owners filled a questionnaire (Figure S1), which included descriptions of the quality of different gaits (walk, trot and canter), information of the performance of the horse, height at the withers and coat colour and markings. The quality of walk was assessed by choosing between options for (a) beat, as pacy (at least sometimes) or four-beat walk and (b) length of the step as long or short. Quality of trot was assessed by choosing (a) beat as two-beat or pacing (at least sometimes), (b) length of the step as long or short and (c) height of the step as low or high. Quality of canter was assessed by choosing between (a) beat of the canter as three-beat or four-beat (at least sometimes), (b) roundness of the steps as round or sharp, (c) long- or short-striding canter and (d) low- or high-stepping canter. Performance of the horse was assessed by choosing between (a) sprinter, (b) medium-distance or (c) long-distance capacity. In addition, performance of harness trotters was qualified as record times in harness racing.

Of these samples, 60 Finnhorses ( 12 horses randomly sampled from each of the four breeding section and 12 horses not registered in any breeding section) and 12 randomly sampled horses from other breeds (Table 1; questionnaire data were available for all these samples as well) were genotyped with the Illumina Equine SNP70 BeadChip in Dr. Van Haeringen Laboratorium (Wageningen, the Netherlands). The chip includes 65157 SNPs over the horse genome. Genotyping call rates averaged 0.9883 , excluding three samples with call rates of $0.3550-0.4186$ (two pony-sized Finnhorses and one Finnhorse, which was not registered to any breeding section), which were not included in further analyses. After pruning for minor allele frequencies ( $m a f=0.05$ ) and linkage equilibrium (with a sliding window of 50 SNPs, shifting the window 5 SNPs forward and removing SNPs with $r^{2}>.5$; -- maf 0.05 -indep-pairwise 505 0.5) with PLINK 1.9 (Chang et al., 2015; Purcell \& Chang, 2018; Purcell et al., 2007), 37445 SNPs remained for further analyses (see also Kvist et al., 2019).

\section{2 | Selection}

We used two approaches to detect signs of selection in the horse genomes based on $F_{\mathrm{ST}}$ outliers. The first method to identify outlier SNPs was BAYESCAN v.2.1 (Foll \& Gaggiotti, 2008). This program is based on a multinomialDirichlet model and searches for differences in allele frequencies between predefined populations assuming correlated allele frequencies through a common migrant gene pool. The difference in allele frequencies between the common gene pool and each population is measured by $F_{\mathrm{ST}}$ coefficients for each locus, and a posterior probability for a model including selection is calculated. Loci with high posterior probability are considered as indicative of selection, " $F_{\mathrm{ST}}$ outlier" loci. We applied the default parameters with 5,000 outputted iterations, thinning interval of 10, 20 pilot runs with a length of 5,000 and an additional burn-in set to 50000 . We searched for outliers between the Finnhorses and the group consisting of mixed breeds based on q-values (minimum false discovery rate at which a locus may become significant) lower than $5 \%$.

The second $F_{\mathrm{ST}}$ outlier-based method used for detection of selection was the hierarchical island model implemented in program ARLEQUiN v.3.5.2.2. (Excoffier \& Lischer, 2010). This method simulates a null distribution and confidence intervals of the observed values and compares locus-specific $F_{\mathrm{ST}}$ values to global $F_{\mathrm{ST}}$ value to detect outliers (Excoffier et al., 2009). The hierarchical island model should reduce the number of false positives. We executed the selection analysis using the hierarchical model with 20000 simulations. We also searched for outliers between pairwise comparisons of the Finnhorse breeding sections the same way. 
TABLE 1 Breeds and numbers of horses included in the study

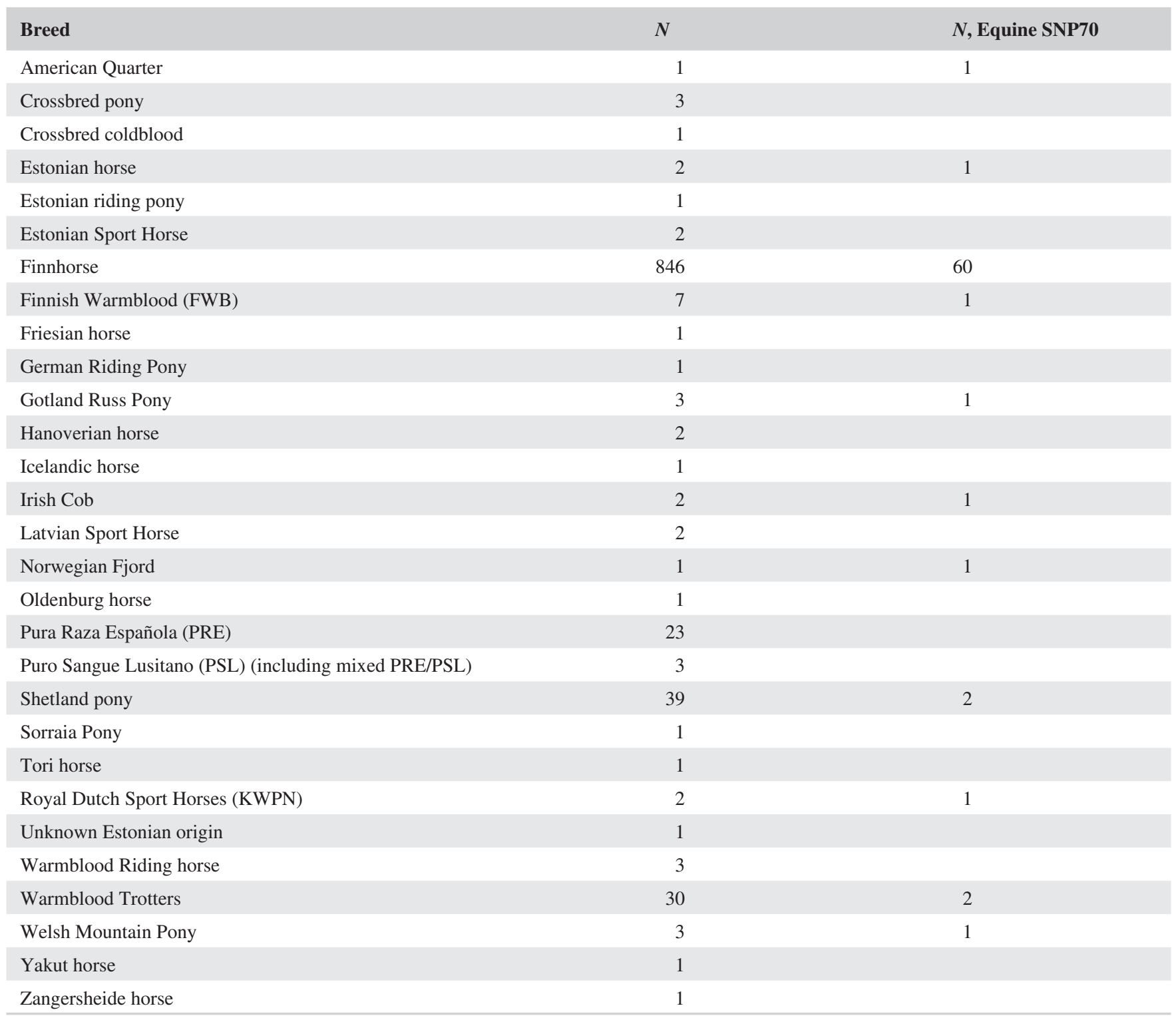

Note: $N=$ number of individuals; $N$, Equine SNP70 = number of individuals genotyped with the Illumina Equine SNP70 BeadChip.

Further, we performed a gene ontology and enrichment analysis using DAvID v.6.8 (Huang et al., 2009) for all the identified genes located close to the SNPs that showed signs for selection, combining results from both BAYESCAN and ARLEQUin. We used Equus caballus annotation file as a background and a significance threshold of $p<.05$.

\section{3 | Screening polymorphisms in candidate genes associated with specific traits}

We chose six shared outlier loci from the selection test in BAYESCAN and ARLEQuin (see results) for further inspection. These specific genes were selected because they have been found to be under selection in other breeds and several polymorphisms are known (Raudsepp et al., 2019). Three of the outlier loci detected by comparisons between Finnhorses and other breeds were in regions, where also several genes involved in coat colour are located.

(i) First of the coat colour-associated genes, KIT, proto-oncogene receptor tyrosine kinase gene, is involved in varying white markings in the coat (sabino, tobiano, dominant white and roan) with at least 32 variable sites (e.g., Grilz-Segera et al., 2020). We examined the most common one, sabino1 (SBI), which is caused by a SNP g2350-13 $G>A$ in intron 16 leading to exon splitting and lack of exon 17. The existence of this SNP was examined as in Brooks and Bailey (2005).

(ii) The second coat colour-associated $F_{\mathrm{ST}}$ outlier was close to gene MITF, coding for melanogenesis-associated transcription factor, which is also associated with 
white coat colour variants and markings. The most common variant, the so-called splashed white phenotype, is caused by a 11-bp insertion in the promoter region of MITF (g.20117302Tdelins 11, SW1; Hauswirth et al., 2012). Existence of this insertion was searched by fragment analysis of a 112-bp amplicon produced by PCR (PCR protocol in Table S1). The PCR products were run with $A B I 3730$ sequencer and scored with GeneMapper v.5 (Applied Biosystems). The white patterning usually resembles as if the horse was dipped in white paint feet and head first, and this colour pattern is also often accompanied by blue eyes. For the gene variants resulting in white markings (KIT and MITF), we selected samples from Finnhorses that showed large white markings (stockings, blaze, spots in the trunk) and/or blue eyes $(N=59)$ and a control group with no white markings $(N=10)$.

(iii)The third coat colour outlier was at the region, where a gene involved in a dilution colour called silver is located. Silver colour is connected with two strongly linked SNPs at the PMEL gene coding for premelanosome protein. This mutation fades the mane and tail of eumelanin (black pigment)-producing horses to flaxen or silver and body colour to chocolate or reddish, but it does not have a fading effect on pheomelanin-producing horses, that is chestnuts (Reissman et al., 2007). The SNPs are also linked with an allele 177 in a microsatellite locus TKY284 (Brunberg et al., 2006), which we genotyped from 550 Finnhorses by fragment analysis of PCR products run on ABI 3730 sequencer and scored with GeneMAPPER v.5 (Applied Biosystems). We then examined the SNP $g 1457 C>T$ that changes an amino acid arginine to cysteine in exon 11 of the $P M E L$ gene (Brunberg et al., 2006; Reissman et al., 2007). For this analysis, we chose samples of Finnhorses, which were registered as silver $(N=5)$, had the allele 177 in preliminary analyses with a microsatellite locus TKY284 $(N=10)$ and/or had flaxen or faded coloured mane and tail $(N=17)$. We amplified and sequenced a 182-bp fragment (PCR and sequencing protocols in Table S1), run the reactions on ABI 3730 automatic sequencer (Applied Biosystems) and scored alleles from the electropherograms using SEQScanner v.2 (Applied Biosystems).

One of the $F_{\mathrm{ST}}$ outliers was close to the myostatin gene $M S T N$, which has previously been connected with racetrack performance (Hill et al., 2010; McGivney et al., 2012). Variation in the intron of this gene $($ g.66493737C $>$ T) producing SNP genotypes TT and CT has been associated with better performance in long distances and $\mathrm{CC}$ genotypes with better performance in short distances (McGivney et al., 2012). We used short amplicon sequencing for detection of the SNP by amplifying and sequencing a 108bp fragment from all our samples (PCR and sequencing protocols in Table S1). The reactions were run and alleles scored as above for PMEL gene. Genotype frequencies were calculated for the four Finnhorse breeding sections and Finnhorses not included into any of the breeding sections, the mixed-breed group, and for subtracted groups of three breeds with over 20 samples (warmblood trotters, Pura Raza Española [PRE] horses and Shetland ponies). The Hardy-Weinberg equilibrium and differences in genotype frequencies between the four Finnhorse breeding sections and horses not included in the breeding sections were tested with the $G$ test. Note that here those horses, which were registered in two breeding sections, were included in both sections. Further, we tested differences in MSTN genotype distribution between Finnhorses classified into different endurance classes (classification into sprinters, medium- or long-distance runners by owners) and used for different purposes (riding, trotting, combined driving, draught, eventing) using the $G$ test. Additionally, we tested whether there were differences in records of harness racing competitions between the genotypes using the $t$ test. Here, we included record times only of horses aged 6 years or more.

We used short amplicon sequencing also for obtaining allele frequencies for the "gait-keeper" gene, doublesex and mab-3-related transcription factor 3 (DMRT3). A nonsense mutation in this gene has been shown to affect the capability of horses to pace and amble (DMRT3_Ser301STOP; Andersson et al., 2012). The "gaited" genotype (AA) has been connected with good performance in Finnhorse trotters and the heterozygote genotype (CA) and homozygote (CC) with good quality gaits in riding horses (Jäderkvist et al., 2015). We amplified and sequenced a 100-bp fragment (PCR and sequencing protocols in Table S1), scored the alleles, calculated genotype frequencies and tested Hardy-Weinberg equilibrium as described above for the MSTN gene. In addition, we tested for differences in DMRT3 genotypes in horses classified according to their gait quality, with the criteria explained above, using the $G$ test.

One of the detected outliers was located close to gene LCORL that codes for a ligand-dependent nuclear receptor corepressor like protein. This is one of the major loci suggested to affect height at the withers (Makvandi-Nejad et al., 2012; Signer-Hasler et al., 2012). To look more into this, we performed a genome-wide association analysis (GWAS) with the SNP data and height at withers in PLink.1.9 (--assoc). 


\section{3 | RESULTS}

\section{1 | Outliers}

BAYESCAN detected altogether 42 and ArLeQuin 55 outlier loci with $F_{\mathrm{ST}}$ values ranging $0.11326-0.19392$ and 0.5000 0.6802 , respectively, in comparisons between Finnhorses and other breeds (Figures 1 and 2; Table S2). Mean $F_{\mathrm{ST}}$ over all loci was $0.0025(S D=0.0006)$ in BAYESCAN and 0.0370 $(S D=0.0825)$ in ArLequin. The two different methods detected altogether 35 common loci. The common outlier loci were found in chromosomes 1 (1 SNPs), 2 (1 SNP), 3 (3 SNPs), 4 (4 SNPs), 5 (1 SNPs), 6 (4 SNPs), 7 (5 SNPs), 8 (1 SNP), 9 (1 SNPs), 10 (1 SNP), 12 (1 SNP), 13 (1 SNP), 14 (2 SNPs), 16 (2 SNPs), 18 (1 SNP), 19 (1 SNP), 21 (1 SNP), 22 (1 SNP), 23 (1 SNP), 30, (1 SNP) and 31 (1 SNP). Four of those loci were in regions where also genes involved in coat colour can be found (chromosome 3, KIT, proto-oncogene receptor tyrosine kinase that is involved in white markings in the coat; chromosome 6, PMEL, premelanosome protein that is known to be involved in silver coat colour; chromosome 10, MCHR2, melanin concentrating hormone receptor 2 that is a possible candidate for colour; and chromosome 16, MITF, melanogenesis-associated transcription factor that is associated with white coat colour variants and markings, "splashed white"). One locus in chromosome 3 was close to LCORL, ligand-dependent nuclear receptor corepressor like, a gene that has been connected with body size, and one locus in chromosome 18 was close to MSTN, myostatin gene that has been connected with performance (e.g., sprinter or long-distance runner types). Several loci are located close to genes, which regulate sugar metabolism (e.g., chromosome 1, SORCS1, Sortilin Related VPS10 Domain Containing Receptor 1; chromosome 4, ICA1, islet cell autoantigen 1, CAVI, caveolin 1, MGAM, maltase-glucoamylase and MGAM2, maltase-glucoamylase 2). In addition, several SNPs were found close to genes involved in immune response (e.g., chromosome 3, CLNK, cytokine-dependent haematopoietic cell linker 4; chromosome 4, NPSRI, neuropeptide S receptor 1, CLEC5A, C-type lectin domain containing 5A; chromosome 6; IL23A, interleukin-23 alpha subunit p19; chromosome 14, FBXW11, F-box and WD repeat domain containing 11; and chromosome 18, STAT1 and STAT4, signal transducer and activator of transcription 1 and 4). Two SNPs were in regions holding many genes of the olfactory receptor family in chromosomes 1 and 12. In comparisons between breeding sections of the Finnhorse, only one outlier was detected by BAYESCAN and five by ARLEQuin in comparisons between harness trotters and pony-sized horses. The SNP BIEC_2_620406 located in chromosome 23, about $500 \mathrm{~kb}$ upstream of the DMRT3 gene, doublesex and mab3-related transcription factor 3 (Table S2), was found by both analyses (BAYESCAN $p<.022)$. A Venn diagram of genes located at the regions of the outlier SNPs detected with BAYESCAN and ARLEQUIN and an intersection detected by both approaches is shown in Figure 2 .

Gene ontology and enrichment analysis by DAVID found that the most important functional annotation clusters were involved in (a) signal transduction and transcriptional regulation, (b) endomembrane systems, (c) apoptosis, (d) cell cortex, (e) cellular responses (to a variety of stimuli) and (f) immunity (Table S3 and Figure S2).

\section{2 | Polymorphisms in candidate genes associated with specific traits}

\subsection{1 | Coat colour}

We found seven Finnhorses carrying the splashed white $(S W 1)$ allele as heterozygotes and no sabino1 (SBI) carriers out of the 59 candidates having white markings and/or blue eyes. None of the control horses carried $S W 1$ or $S B 1$ genotypes. Studying the pedigrees of $S W 1$ horses revealed that four of these horses were offspring of the same stallion, whose half-sister was also tested positive for the $S W 1$ mutation. Of the other two horses, one was offspring of another stallion, also registered as carrying $S W 1$, and one did not have any ancestors registered as $S W 1$.

Fourteen of the 32 suspected carriers of the silver mutation were heterozygotes for the mutation, all the rest were homozygous for the wild allele. One of the homozygotes for the wild allele carried the 177 allele of microsatellite TKY284 linked with the silver mutation, two of the heterozygotes did not carry the 177 allele and three failed to amplify. Seven of the fourteen heterozygotes shared a same silver stud in their pedigrees and two shared another silver stud, the remaining five did not share any recent ancestors.

\subsection{2 $\quad$ Performance and gaits}

The MSTN genotypes showed no differences between Finnhorse breeding sections nor in horses not registered in any of the breeding sections ( $G$ test values $0.665-5.109$, all $p$-values >.070; Table 2). However, the difference between Finnhorses and mixed-breed group was highly significant $(G=32.773, p<.001)$, there were in general much more TT homozygotes (long-distance runners) and less CC homozygotes (sprinters) in Finnhorses than in other breeds. However, also warmblood trotters and PRE-horses had more TT homozygotes and fewer CC homozygotes than the other breeds we studied (Table 2). We found no effect of the MSTN genotype on descriptions of the horses by their owners as sprinters, medium- or long-distance horses $(N=772$, $G=3.605, d f=2, p=.462$ ), nor on the usage of horses 


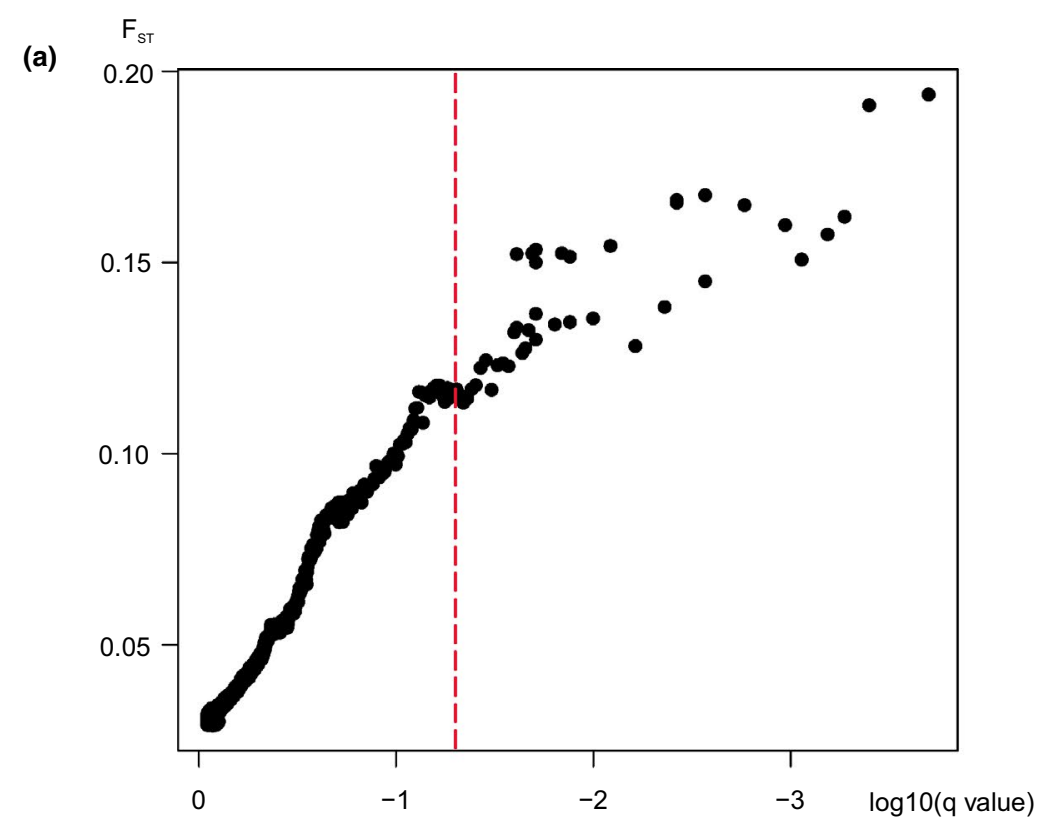

(b)

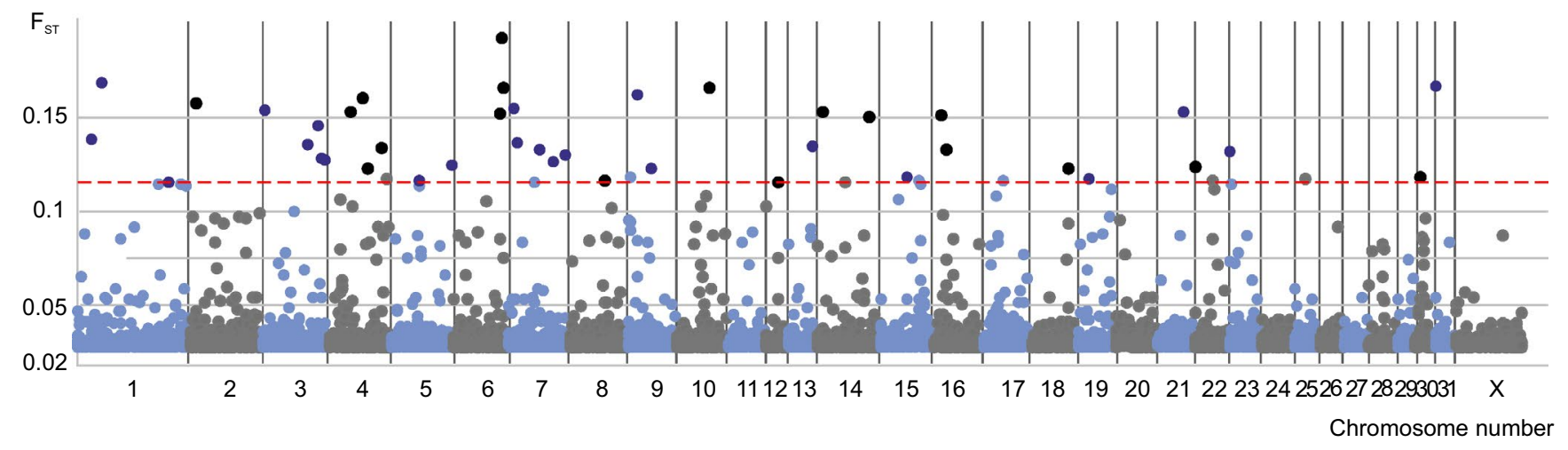

(c)

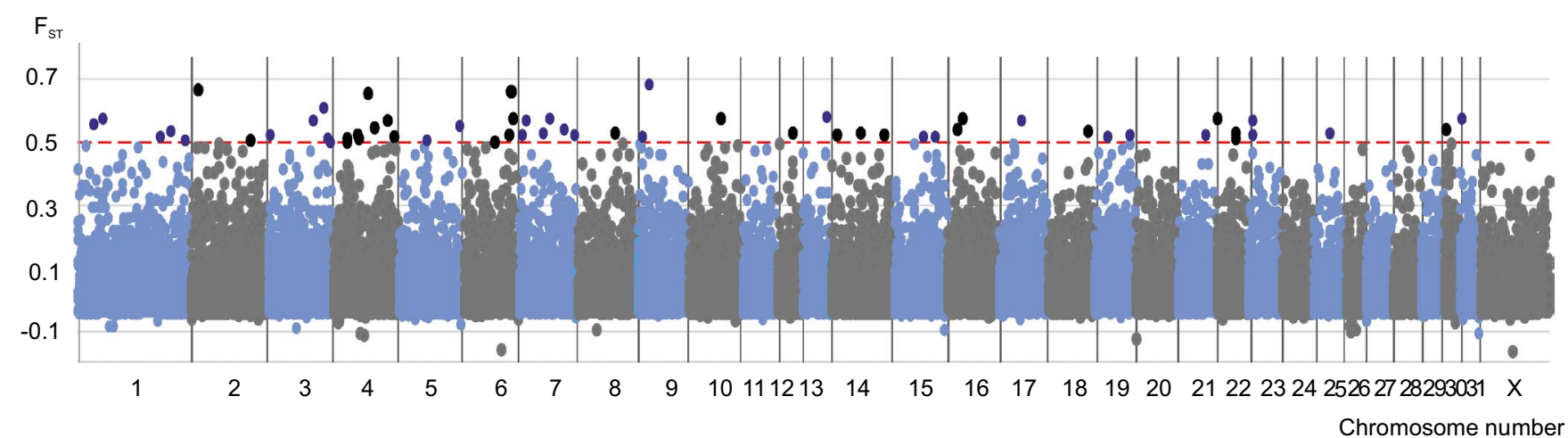

F I G U RE 1 Results from the selection analysis. (a) $F_{\mathrm{ST}}$ values of all loci plotted against $\log _{10}(q$-value $)$ from BAYESCAN. The dashed vertical line shows the $\log _{10}\left(q\right.$-value) equalling $q=0.05$. (b) $F_{\mathrm{ST}}$ values from BAYESCAN plotted along the 31 autosomal equine chromosomes and $\mathrm{X}$ chromosome. Dashed red horizontal line $=$ smallest $F_{\mathrm{ST}}(0.1133)$ of the loci with $\log 10(q$-value $)$ equalling $q=0.05$, shaded colours above the line $=\operatorname{loci}$ with $\log 10(q$-value $)$ above $q=0.05$. (c) $F_{\mathrm{ST}}$ values from ArLeQun plotted along the 31 autosomal equine chromosomes and $\mathrm{X}$ chromosome. $F_{\mathrm{ST}}=0.5$ is shown by a dashed red horizontal line and shaded colours above the line $=$ loci with $F_{\mathrm{ST}}>0.5$ [Colour figure can be viewed at wileyonlinelibrary.com] 


\section{BAYESCAN}

\section{ARLEQUIN}

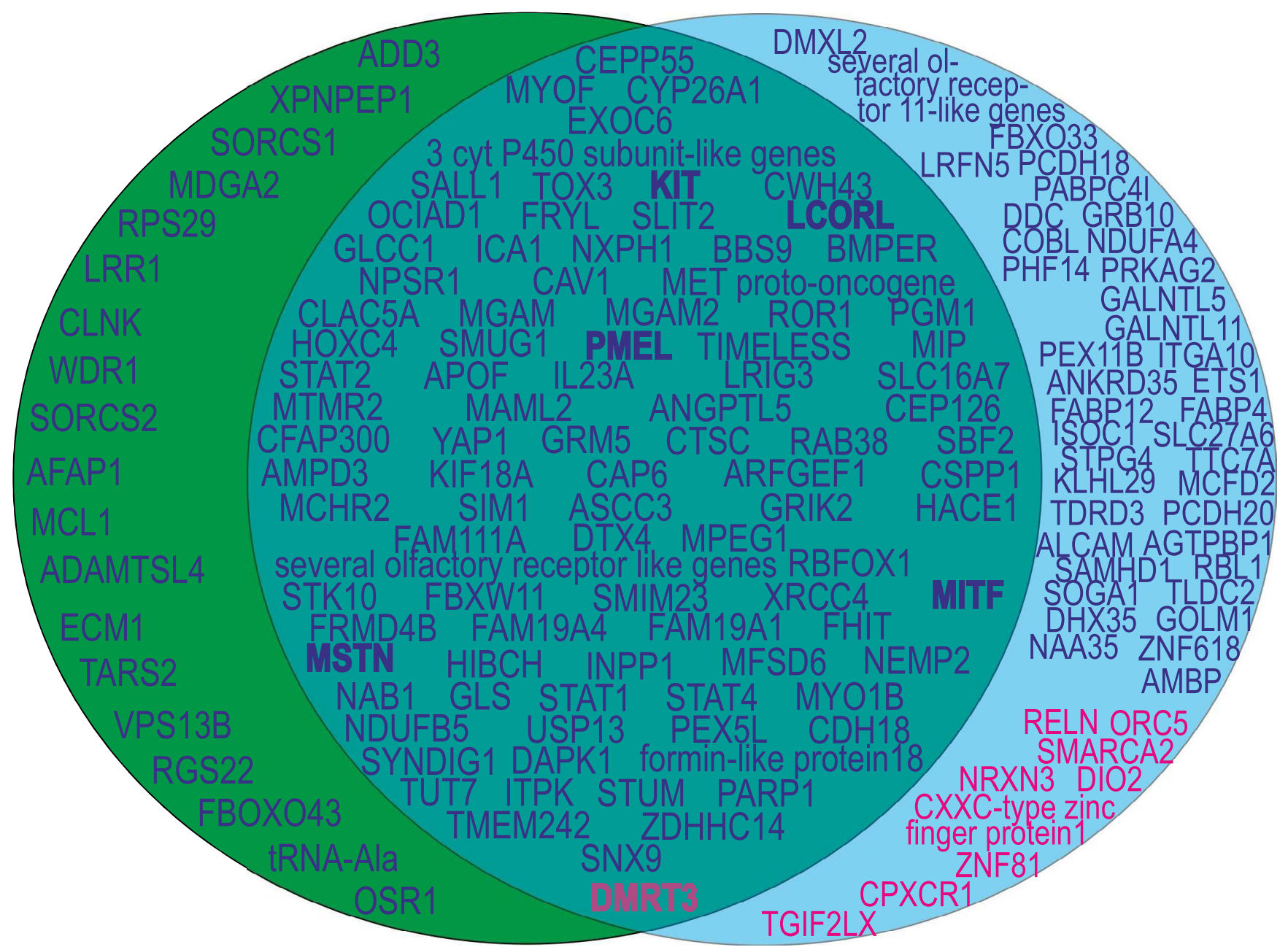

F I G U RE 2 A Venn diagram showing the genes located at the regions of outlier SNPs. Green background shows the results from BAYESCAN, blue background the results from ARLEQUIN and intersection the genes located at the regions of outlier SNPs detected by both methods. Blue text denotes the results from comparisons between Finnhorses and other breeds, red the comparison between pony-sized Finnhorses and harness trotters and bold the candidate genes associated with specific traits examined in more detail. Full names of the genes are in Table S2 [Colour figure can be viewed at wileyonlinelibrary.com]

(as riding, trotting, combined driving, draught, eventing; $N=768, G=8.557, d f=2, p=.381$ ). For trotters, there was no effect of the MSTN genotype on the records of the horses (car start: $N=76, t=0.453, p=.652$ [two-tailed], rolling start: $N=99, t=0.695, p=.488$ ). All groups were in Hardy-Weinberg equilibrium, except the mixed-breed group $(G=10.004, d f=2, p=.007)$.

Finnhorses differed from the mixed-breed group in the frequency of the DMRT3 genotypes, there were significantly fewer CC homozygotes and more CA heterozygotes (both associated with good gaits for riding horses) than expected $(G=164.501, d f=2, p=.000$; Table 2$)$. There were no $\mathrm{CC}$ homozygotes in our sample of warmblood trotters. There were also differences between the Finnhorse breeding sections (riding horses vs. horses not in the studbook,
$G=13.953, d f=2, p=.0009$; trotters vs. horses not in the studbook, $G=10.195, d f=2, p=.006$; pony-sized horses vs. horses not in the studbook, $G=9.818, d f=2, p=.007$; riding horses vs. trotters, $G=9.017, d f=2, p=.011$; riding horses vs. draught horses, $G=7.786, d f=2, p=.0210$; trotters vs. pony-sized horses, $G=8.832, d f=2, p=.012$; and draught vs. pony-sized horses, $G=7.019, d f=2, p=.030$ ), but only the difference between riding horses versus horses not in the studbook remained significant after the Bonferroni correction, riding horses having more of the $\mathrm{CC}$ homozygotes and less of the AA homozygotes (the "gaited" genotype). All groups were in Hardy-Weinberg equilibrium, except the mixed-breed group $(G=58.800, d f=2, p<.001)$.

Finnhorses with four-beat walk had less DMRT3 AA homozygotes and more $\mathrm{CC}$ homozygotes than horses showing 
TA B LE 2 MSTN and DMRT3 genotype frequencies in the four breeding sections, combined mixed breeds and of three breeds with more than

26 samples

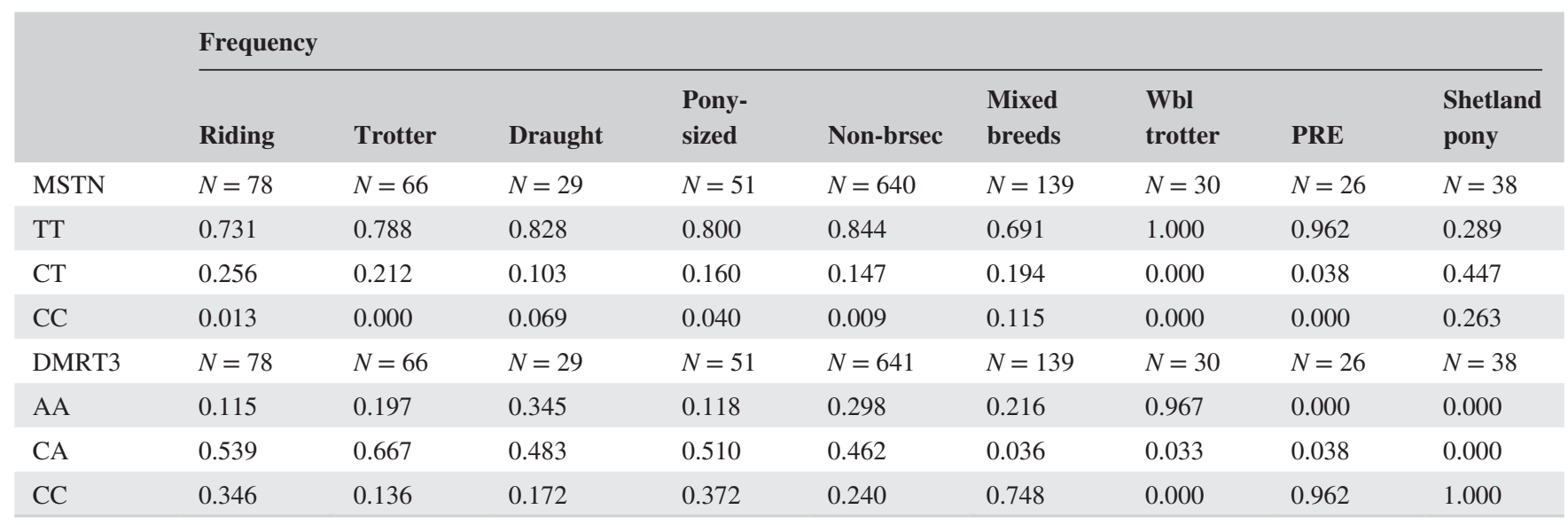

Note: Non-brsc $=$ Finnhorses not included to any breeding section, Wbl trotter $=$ Warmblood trotters, PRE $=23$ samples from Pura Raza Espanola and 3 from Puro Sangue Lusitano or mixed Pura Raza Espanola/Puro Sangue Lusitano, $N=$ sample size. $M S T N$ genotypes: TT = "long distance," CT = "medium distance," $\mathrm{CC}=$ "sprinter." DMRT3 genotypes: AA = "gaited," good for trotters, CA and CC = "non-gaited," good for riding.

pacy walk $(G=33.819, d f=2, p<.001$; Figure 3a). There was no influence of the DMRT3 genotype to length of the steps $(G=4.877, d f=2, p=.087$; Figure 3a). Finnhorses with two-beat trot had less AA homozygotes and more CC homozygotes than horses showing pace $(G=104.595, d f=2$, $p<.001$; Figure $3 b$ ). Horses with short trotting step length also had less AA homozygotes and more CC homozygotes and CA heterozygotes than horses with long-trotting steps $(G=15.716, d f=2 ; p<.001$; Figure $3 b)$. There was no effect on the height of the steps $(G=4.695, d f=2, p=.096$; data not shown) nor on the liability of trotters to break into canter ( $G=2.249, d f=2, p=.325$; data not shown). Finnhorses with three-beat canter and round movements had less AA homozygotes and more CC homozygotes and CA heterozygotes than horses that at least sometimes present four-beat canter and have sharp movements $(G=39.654, d f=2, p<.001$; Figure $3 \mathrm{c}$ ). Horses with short-striding and high-stepping canter also had less AA homozygotes and more CC homozygotes and CA heterozygotes than horses with long-striding and low-stepping canter $(G=6.194, d f=2, p<.05$ and $G=16.043, d f=2, p<.001$, respectively; Figure 3c). All tests with $p$-values below .001 remained significant also after the Bonferroni correction.

\subsection{3 | Height at withers}

One SNP locus (BIEC2_849774) detected by both BAYESCAN and ARLEQUiN in comparisons between Finnhorses and other breeds was located in chromosome 3 close to (about $180 \mathrm{~Kb}$ upstream) $L C O R L$ gene that codes for a ligand-dependent nuclear receptor corepressor like protein (Table S2a,c) and is one of the major loci suggested to affect height at the withers (Makvandi-Nejad et al., 2012; Signer-Hasler et al., 2012). In addition to this SNP identified as an outlier by both BAYESCAN and ARLEQUin, GWAS showed the most significant result for BIEC2_808625 $\left(p=1.19 \times 10^{-12}\right)$, another SNP in chromosome 3 close to LCORL gene (about $70 \mathrm{~Kb}$ upstream).

\section{4 | DISCUSSION}

Using BayeScan and Arlequin, we detected 42 and $55 F_{\text {ST }}$ outlier SNPs, respectively, between Finnhorses and other breeds, of which several were of special interest as they were connected to traits, which (a) were strongly selected for at the dawn of the Finnhorse breed (coat colour and size), (b) are related to the usage of the breed (performance and gaits) or (c) are associated with metabolism and immunity system. Gene ontology analysis of genes located at the proximity to the SNPs proposed to be under selection classified the genes in functional clusters including signal transduction, transcriptional regulation, cellular responses and immunity.

As noted above, several of the outliers were located close to genes affecting coat colour as expected. Most of the colour genes are involved in melanogenesis, either via synthesis of melanin, properties of melanocytes or migration of melanocytes from the neural crest (Thiruvendakan et al., 2008). However, we did not see any selection signs close to the $M C 1 R$ gene (Melanocortin-1 Receptor), which would have been expected to have arisen due to selection for chestnut colour, as this gene is responsible for production of red or black pigment. One of the detected outlier SNPs related to colour was close to KIT, proto-oncogene receptor tyrosine kinase gene, that is crucial in melanocyte development. This gene has been connected with white coat markings. Several polymorphisms have been described in this gene, producing a variety of different white patterns in coat colouration, from 
(a) Walk

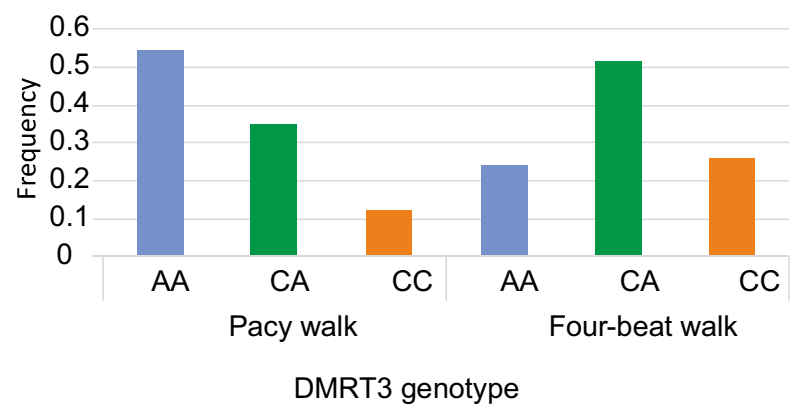

(b) Trot

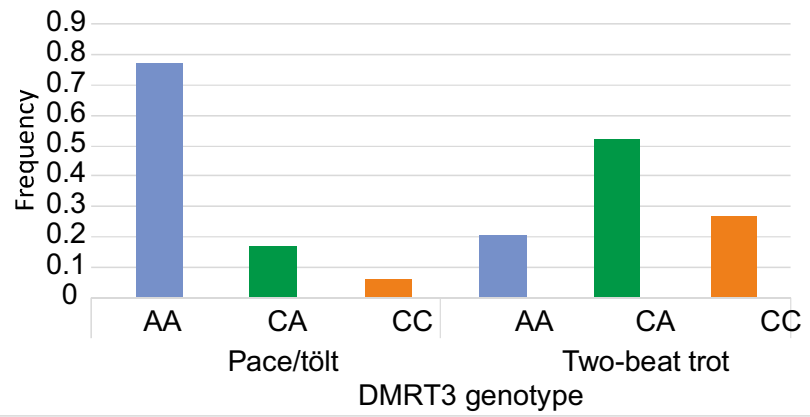

(c) Canter
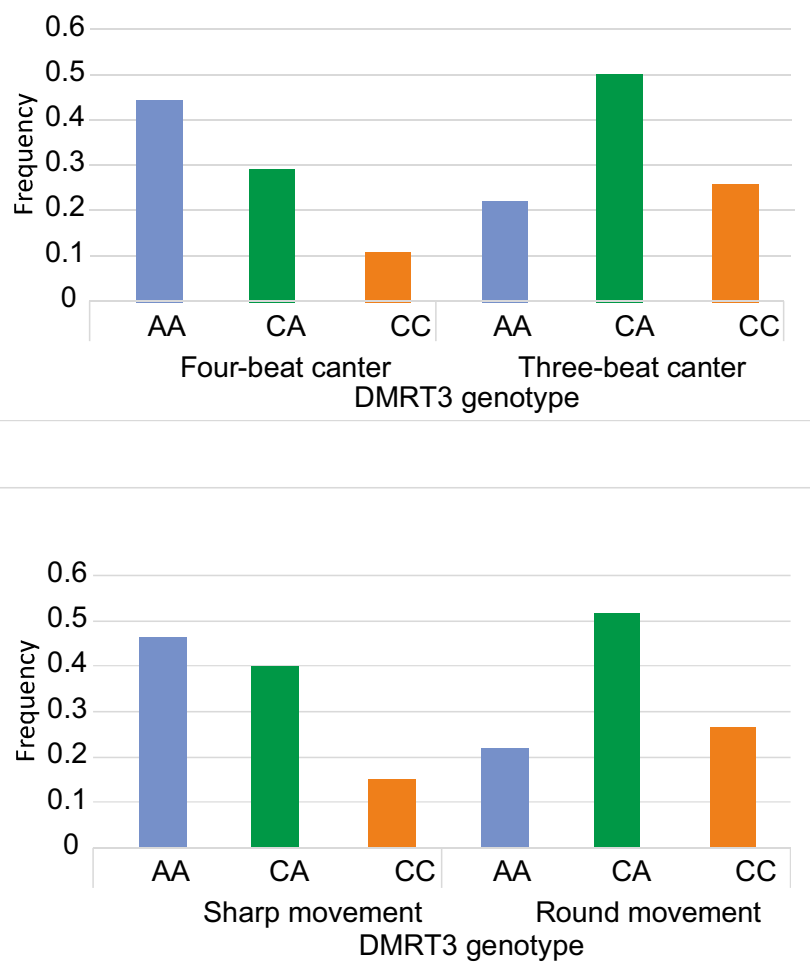
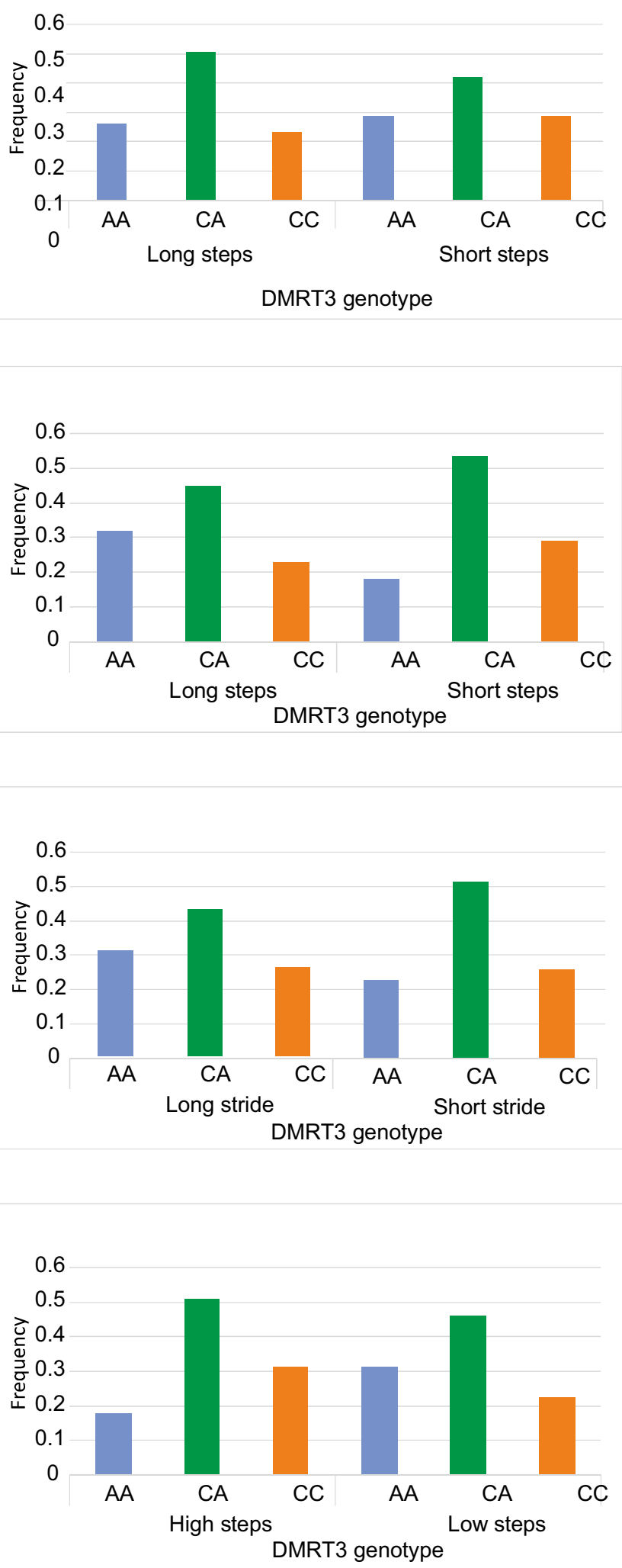

F I G U RE 3 Frequencies of DMRT3 genotypes classified according to quality of gaits among Finnhorses in (a) walk, (b) trot and (c) canter [Colour figure can be viewed at wileyonlinelibrary.com] 
totally white horses to sabinos and roans or to small patches of white in legs, face and belly (Haase et al., 2007, 2009; Hauswirth et al., 2013). In Finnhorses, roans are extremely rare, but have occasionally been detected (Perttunen, 2007). Another colour gene located close to an outlier SNP was MITF, melanogenesis-associated transcription factor gene. This gene is as well associated with a variety of white coat colour variants and markings called splashed white. In addition, one further gene, $P A X 3$, paired box gene 3 , is connected with this type of coloration (Hauswirth et al., 2012). Based on the phenotype, it is difficult to conclude which specific variant is responsible for a particular coloration. We found evidence of only splashed white (SWI) causing white coat colour patches in Finnhorses, no sabinos were detected. At least three lineages were found to carry the $S W 1$ mutation. Previously, the rare Finnhorses with white patches were believed to be sabinos (Perttunen, 2007), but based on our results, they are more likely splashed whites.

A further colour-related SNP outlier was located close to PMEL, premelanosome protein gene. At least two variants of this gene are linked with silver coat colour (Brunberg et al., 2006; Reissman et al., 2007). We tested 550 Finnhorses using a microsatellite linked with PMEL (TKY284; Brunberg et al., 2006) and found ten horses carrying the allele connected with silver variants. By sequencing, we confirmed fourteen silver carriers. These included all the horses registered as silver and all the horses carrying the 177 allele of the TKY284 microsatellite, except for one horse, which carried the 177 allele but was homozygous for the wild allele at the silver locus. In addition, two of these fourteen horses did not have the 177 allele, but were found to carry the silver variant. Thus, the microsatellite allele is not perfectly linked with the silver mutation. Several lineages of Finnhorses are known to carry silver variants, and we detected the presence of the variant in seven different lineages. More of them will likely emerge with the ease of commercial testing possibilities for "colour genes." The silver mutation is dominant; thus, heterozygotes for this mutation also express the silver phenotype except for chestnuts that lack the eumelanin pigment. All the tested horses were heterozygotes in this study. The mutation in PMEL gene has pleiotropic effects and is also causative of equine multiple congenital ocular anomalies (MCOA) syndrome, which is a heritable eye disorder (Andersson et al., 2013). Horses homozygote for the silver mutation also express a range of ocular defects with heterozygotes expressing much less severe symptoms (Andersson et al., 2013).

In addition to these known colour genes, one SNP outlier was located close to MCHR2, melanin concentrating hormone receptor 2 . This gene has been shown to affect fish skin coloration (Takahashi et al., 2007), but the function of the protein produced by this gene is still largely unknown in mammals. In humans, it is expressed in brain and not in peripheral tissues (An et al., 2001).
Besides colour, Finnhorses were strongly selected for size at the founding of the breed. Pony-sized horses (withers height at most $148 \mathrm{~cm}$ ) were not accepted for breeding until the establishment of a separate breeding section for the pony-sized Finnhorses in 1971. We detected one SNP outlier close to a transcription factor LCORL, ligand-dependent nuclear receptor corepressor like gene. This gene has been shown to be the top locus of the four major loci, which together explained $83 \%$ of the height at withers in horses (Makvandi-Nejad et al., 2012) and emerged as an influential locus also in a study of Franches-Montagnes horses (Signer-Hasler et al., 2012) and German Warmbloods (Tetens et al., 2013). Increased expression of this gene is connected to small size and decreased expression to bigger size (Metzger et al., 2013). This outlier was also strongly associated with size in our GWAS, suggesting that it indeed is connected with height at withers in Finnhorses.

Further, an SNP outlier was detected close to MSTN, myostatin gene. This gene has been connected with muscle mass, body conformation related to muscularity (e.g., skeletal sturdiness indicated by cannon bone circumference) and also performance. There are a couple of variants located in the promoter region of this gene that have been connected with heavy or light stature (Dall'Olio et al., 2014) and a variant in the first intron that has been connected with racing performance (Hill et al., 2010; McGivney et al., 2012). We sequenced the variant of the first intron and found that there were more TT homozygotes in Finnhorses compared with the mixed-breed groups and especially so in the draught horses and in horses not registered to breeding sections. The TT genotype frequencies have been shown to be high especially in horses with greater stamina, whereas the CC homozygotes perform well in fast and short-distance races (Bower et al., 2012; Hill et al., 2010; McGivney et al., 2012). In Finnhorses, the variants of the first intron have been found to be significantly associated with harness racing performance (Bas Con, 2017); however, this association was not found in closely related Norwegian-Swedish Coldblooded Trotters (Velie et al., 2018) nor in Shetland ponies (Bas Con, 2017). Further, none of our outlier $\mathrm{F}_{\mathrm{ST}} \mathrm{s}$ were located in the same regions detected by Velie et al. (2019) in their study of trotting racing ability that included Norwegian-Swedish Coldblooded Trotters. We found no association of the intron variants with racing records, nor with performance type (i.e., sprinter, medium- or long-distance horse) or usage of horses (riding, trotting, combined driving, draught, eventing). This might be due to long-lasting directional selection against the CC genotypes, stemming from the use of the Finnish horses in agriculture and forestry, where greater stamina and hardiness were likely valued over sprinting performance for horses working long hours. Conformation other than that directly related to muscularity also matters in the athletic performance of horses, which likely partly explains why we found no 
association of the intron variants with harness racing records and performance types. After all, a TT homozygote horse with suitable proportional relationships of body and limb segments for speed is almost certainly faster than a CC homozygote horse with an unsuitable conformation for speed from purely biomechanical reasons. Unfortunately, genotypes associated with most "conformation phenotypes" (e.g., relative lengths of limb segments, neck, back, etc.) are still unknown.

The "gait-keeper" gene DMRT3 has been connected with harness racing performance as well. A premature stop codon in the gene allows alternate gaits, pace and ambling gaits due to its effect on the development of the locomotor network in the spinal cord. This "gaited" phenotype (genotype AA) appears in high frequency in Icelandic horses, famous for their ability to perform four or five gaits (Andersson et al., 2012), and is suggested to originate from mediaeval England (Wutke et al., 2015). It has also been suggested that the "gaited" mutation arose during or soon after the domestication of horses and was later imported to England (Staiger et al., 2017). In a survey of 141 breeds, AA genotypes were frequent in gaited breeds and breeds used for harness trotting (Promerová et al., 2014). In Finnhorses, it has already been shown that AA genotypes perform better in harness racing and CC and CA genotypes have better quality gaits for riding (Jäderkvist et al., 2015) and many individuals are known to show pace in walk or trot, at least occasionally. In Nordic coldblood trotters, AA genotypes were also shown to perform better in harness racing than $\mathrm{CA}$ and $\mathrm{CC}$ genotypes and they had higher estimated breeding values for trotting performance as well (Jäderkvist et al., 2014). We found indications of selection for this gene in comparisons between breeding sections of trotters and pony-sized horses, higher frequencies of AA genotypes in trotters and draught horses compared with riding and pony-sized horses and higher frequency of CC genotypes in riding and pony-sized horses compared with trotters and draught horses. Compared with the mixed-breed group, CA heterozygotes are more common in Finnhorse, perhaps due to the common gene pool and the "all-around" usage of the breed as a whole. We studied the effect of the genotypes in more detail than previously using the questionnaire with detailed questions related to quality of the walk, trot and canter, and it seemed that the clearest effect is related to the rhythm (beat) of the steps in all gaits. However, there is room for errors, as the questions could not be standardized in any way.

Of the other SNP outliers detected, several were found in regions where genes regulating glucose and other carbohydrate metabolism are located, and many of those have been connected with diabetes in humans (e.g., SORCS1, Sortilin Related VPS10 Domain Containing Receptor 1 in chromosome 1; CAV1, caveolin 1, MGAM, maltase-glucoamylase and MGAM2, maltase-glucoamylase 2 in chromosome 4; Table S2). Equine metabolic syndrome (EMS) is a cluster of clinical abnormalities that predispose horses to laminitis, caused by insulin resistance and/or obesity (Geor, 2008). Many pony and native horse breeds are suggested to have high risk of EMS, likely due to their high metabolic efficiency, leading easily to obesity. Profuse ingestion of carbohydrates, especially starch from pastures, is commonly causing the acute form of laminitis (Katz \& Bailey, 2012). Even though there are no studies of prevalence of laminitis in Finnhorses that we are aware of, the breed does gain weight easily and laminitis is not rare.

A common disease in Finnhorses is summer eczema or insect bite hypersensitivity (IBH), an allergic skin condition thought to be caused by biting insects, especially of the genus Culicoides (Hallamaa, 2009). This reaction is thought to be mediated mainly through immunoglobulin $\mathrm{E}$ (IgE; Wagner, 2015), produced by stimulation of T-cell-derived cytokines (Bos et al., 1992). We found $F_{\mathrm{ST}}$ outliers in regions close to genes associated with immune system and $\mathrm{IgE}$, for example STAT1 and STAT2 (signal transducer and activator of transcription) genes, IL23A (interleukin 23, alpha subunit p19), CLEC5A (C-type lectin domain containing 5A) and NPSR1 (neuropeptide $S$ receptor 1; Table S2). STAT genes are present in several homologues in the genome, and in humans, defects, for example in STAT3 gene, have been connected with hyper-IgE syndrome and atopic dermatitis (Boos et al., 2014; Shuai \& Liu, 2003) and NPSRI has been proposed to be involved in IgE-mediated diseases in humans, such as allergic eczema and asthma (Acevedo et al., 2017). CLEC5A has been connected with innate immunity against several pathogens (Chen et al., 2017) and IL23A with inflammation, immune response and cell differentiation and survival (Brocker et al., 2010). However, different studies have detected several and commonly non-overlapping genomic regions that are associated with IBH (e.g., Shrestha et al., 2015) and various results of the association of IgE levels with IBH. For example, in a study of Kladruber horses (an old Czech horse breed) by Vychodilova et al. (2013), there was no difference between IgE levels in IBH affected versus non-affected horses, but in Icelandic horses studied by Wilson et al. (2006), a significant difference was found. This might be due to existence of breed-specific genetic associations (Shrestha et al., 2015). Thus, immune system-related genes found in our study can be regarded as candidate genes worth of detailed studies in relation to the summer eczema in Finnhorses.

Further, our $F_{\mathrm{ST}}$ outlier analyses detected SNPs located in genomic regions containing several olfactory receptor-like genes. Previous studies have found large numbers of non-synonymous variants in horse olfactory receptor (and immunity-related) genes, and these loci have turned up in selection studies as well (e.g., Fawcett et al., 2019; Gurgul et al., 2019; Metzger et al., 2014; Orlando et al., 2013). These genes are assumed to be important in mammalian behaviour-for example to find food and mates and to evaluate the environment (Issel-Tamer \& Rine, 1997; Niimura et al., 2014), and they 
seem to appear consistently as targets of selection in equine studies.

\section{CONCLUSIONS}

We found evidence of selection in the Finnhorse when compared to other breeds in several regions of the genome. Many of the genes at these regions affect height, movement, performance, colour, sugar metabolism, immune response and olfaction and are connected with signal transduction, transcriptional regulation, cell death and cellular responses. On the contrary, selection has not yet resulted in strong differentiation among the breeding sections within the breed. We found strong evidence of divergence in one region, where DMRT3 gene is located, and only between two breeding sections, the harness trotters and pony-sized horses. Thus, selection for over 100 years since the breed was founded has induced differentiation through selection. However, time since foundation of the breeding sections has been too short or selection too weak for differences to emerge. This can also be due to acceptance of new horses into the breeding sections from the common gene pool and acceptance of individuals to more than one breeding section. On the other hand, this practice helps to maintain inbreeding at a lower level and effective population sizes higher than they would be without this practice, which are both matters of concern in the breed.

\section{ACKNOWLEDGEMENTS}

We thank all the horse owners, who provided us samples of their horses, the Oulu Horse Hospital (Oulun Hevosklinikka Oy) and Laura Juntunen for collaborating with sample collection, and Minna Mäenpää from the Finnish Trotting and Breeding Association for helping us to contact some of the horse owners. We are grateful for the priceless help from Soile Alatalo and Hannele Parkkinen-Oinas in the laboratory and for Dr. Ari-Pekka Kvist for the help with IT problems. This study was funded by the Finnish Cultural Foundation and the University of Oulu.

\section{CONFLICT OF INTEREST}

The authors declare no conflict of interest.

\section{DATA AVAILABILITY STATEMENT}

The SNP data are openly available at the European Variation Archive by accession number PRJEB38010 (https://www. ebi.ac.uk/ena/browser/view/PRJEB38010).

\section{ORCID}

Laura Kvist iD https://orcid.org/0000-0002-2108-0172 Johanna Honka iD https://orcid.org/0000-0003-2536-5869 Markku Niskanen iD https://orcid.org/0000-0003-4341-146X Jouni Aspi iD https://orcid.org/0000-0002-2451-3201

\section{REFERENCES}

Ablondi, M., Dadousis, C., Vasini, M., Eriksson, S., Mikko, S., \& Sabbioni, A. (2020). Genetic diversity and signatures of selection in a native Italian horse breed based on SNP data. Animals, 10, 1005. https://doi.org/10.3390/ani10061005

Acevedo, N., Ezer, S., Kebede, M. S., Gaertner, V. D., Söderhäll, C., D'Amato, M., Kabesch, M., Melén, E., Kere, J., \& Pulkkinen, V. (2017). Neuropeptide S (NPS) variants modify the signaling and risk effects of NPS Receptor 1 (NPSR1) variants in asthma. PLoS One, 12(5), e0176568. https://doi.org/10.1371/journal.pone.0176568

An, S., Cutler, G., Zhao, J. J., Huang, S. G., Tian, H., Li, W., Liang, L., Rich, M., Bakleh, A., Du, J., Chen, J. L., \& Dai, K. (2001). Identification and characterization of a melanin-concentrating hormone receptor. Proceeding of the National Academy of Sciences of the United States of America, 98(13), 7576-7581. https://doi. org/10.1073/pnas.131200698

Andersson, L. S., Larhammar, M., Memic, F., Wootz, H., Schwochow, D., Rubin, C.-J., Kalicharan, P., Arnason, T., Wellbring, L., Hjälm, G., Imsland, F., Petersen, J. L., McCue, M. E., Mickelson, J. R., Cothran, G., Ahituv, N., Roepstorff, L., Mikko, S., Vallstedt, A., ... Kullander, K. (2012). Mutations in DMRT3 affect locomotion in horses and spinal circuit function in mice. Nature, 488, 642-646. https://doi.org/10.1038/nature11399

Andersson, L. S., Wilbe, M., Viluma, A., Cothran, G., Ekesten, B., Ewart, S., \& Lindgren, G. (2013). Equine multiple congenital ocular anomalies and Silver coat colour result from the pleiotropic effects of mutant PMEL. PLoS One, 8(9), e75639. https://doi.org/10.1371/ journal.pone.0075639

Bas Con, L. (2017). The role of myostatin polymorphisms in the Finnhorse and Shetland pony breeds. Master's Thesis. Department of Animal Breeding and Genetics, Faculty of Veterinary Medicine and Animal Sciences, Swedish University of Agricultural Sciences.

Beale, H., \& Ostrander, E. A. (2012). Sizing up dogs. Current Biology, 22(9), R316. https://doi.org/10.1016/j.cub.2012.02.013

Boos, A. C., Hagl, B., Schlesinger, A., Halm, B. E., Ballenberger, N., Pinarci, M., Heinz, V., Kreilinger, D., Spielberger, B. D., SchimkeMarques, L. F., Sawalle-Belohradsky, J., Belohradsky, B. H., Przybilla, B., Schaub, B., Wollenberg, A., \& Renner, E. D. (2014). Atopic dermatitis, STAT3- and DOCK8-hyper-IgE syndromes differ in IgE-based sensitization pattern. Allergy, 6(7), 943-953. https:// doi.org/10.1111/all.12416

Bos, J. D., Wierenga, E. A., Sillevis Smitt, J. H., van der Heijden, F. L., \& Kapsenberg, M. L. (1992). Immune dysregulation in atopic eczema. Archives of Dermatology, 128(11), 1509-1512. https://doi. org/10.1001/archderm.1992.01680210087014

Bower, M., McGivney, B., Campana, M., Campana, M. G., Gu, J., Andersson, L. S., Barrett, E., Davis, C. R., Mikko, S., Stock, F., Voronkova, V., Bradley, D. G., Fahey, A. G., Lindgren, G., MacHugh, D. E., Sulimova, G., \& Hill, E. W. (2012). The genetic origin and history of speed in the thoroughbred racehorse. Nature Communications, 3, 643. https://doi.org/10.1038/ncomms1644

Brocker, C., Thompson, D., Matsumoto, A., Nebert, D. W., \& Vasiliou, V. (2010). Evolutionary divergence and functions of the human interleukin (IL) gene family. Human Genomics, 5, 30. https://doi. org/10.1186/1479-7364-5-1-30

Brooks, S. A., \& Bailey, E. (2005). Exon skipping in the KIT gene causes a Sabino spotting pattern in horses. Mammalian Genome, 16, 893-902. https://doi.org/10.1007/s00335-005-2472-y

Brunberg, E., Andersson, L., Cothran, G., Sandberg, K., Mikko, S., \& Lindgren, G. (2006). A missense mutation in PMEL17 is associated 
with the Silver coat color in the horse. BMC Genetics, 7, 46. https:// doi.org/10.1186/1471-2156-7-46

Chang, C. C., Chow, C. C., Tellier, L. C. A. M., Vattikuti, S., Purcell, S. M., \& Lee, J. J. (2015). Second-generation PLINK: Rising to the challenge of larger and richer datasets. GigaScience, 4, 7. https://doi. org/10.1186/s13742-015-0047-8

Chen, S. T., Li, F. J., Hsu, T. Y., Liang, S. M., Yeh, Y. C., Liao, W. Y., Chou, T. Y., Chen, N. J., Hsiao, M., Yang, W. B., \& Hsieh, S. L. (2017). CLEC5A is a critical receptor in innate immunity against Listeria infection. Nature Communications, 8, 299. https://doi. org/10.1038/s41467-017-00356-3

Cieslak, M., Reissmann, M., Hofreiter, M., \& Ludwig, A. (2011). Colours of domestication. Biological Reviews of the Cambridge Philosophical Society, 86(4), 885-899. https://doi. org/10.1111/j.1469-185X.2011.00177.x

Dall'Olio, S., Wang, Y., Sartori, C., Fontanesi, L., \& Mantovani, R. (2014). Association of myostatin (MSTN) gene polymorphisms with morphological traits in the Italian Heavy Draft horse breed. Livestock Science, 160, 29-36. https://doi.org/10.1016/j. livsci.2013.12.002

Do, K.-T., Lee, J.-H., Lee, H.-K., Kim, J., \& Park, K.-D. (2014). Estimation of effective population size using single-nucleotide polymorphism (SNP) data in Jeju horse. Journal of Animal Science and Technology, 56, 28. https://doi.org/10.1186/2055-0391-56-28

Excoffier, L., Hofer, T., \& Foll, M. (2009). Detecting loci under selection in a hierarchically structured population. Heredity, 103, 285298. https://doi.org/10.1038/hdy.2009.74

Excoffier, L., \& Lischer, H. E. L. (2010). Arlequin suite ver 3.5: A new series of programs to perform population genetics analyses under Linux and Windows. Molecular Ecology Resources, 10(3), 564 567. https://doi.org/10.1111/j.1755-0998.2010.02847.x

Fages, A., Hanghøj, K., Khan, N., Gaunitz, C., Seguin-Orlando, A., Leonardi, M., McCrory Constantz, C., Gamba, C., Al-Rasheid, K. A. S., Albizuri, S., Alfarhan, A. H., Allentoft, M., Alquraishi, S., Anthony, D., Baimukhanov, N., Barrett, J. H., Bayarsaikhan, J., Benecke, N., Bernáldez-Sánchez, E., ... Orlando, L. (2019). Tracking five millennia of horse management with extensive ancient genome time series. Cell, 177, 1419-1435.e31. https://doi. org/10.1016/j.cell.2019.03.049

Fawcett, J. A., Sato, F., Sakamoto, T., Iwasaki, W. M., Tozaki, T., \& Innan, H. (2019). Genome-wide SNP analysis of Japanese Thoroughbred racehorses. PLoS One, 14, e0218407. https://doi. org/10.1371/journal.pone.0218407

Finnish Trotting and Breeding Association (2017). Suomenhevosen jalostusohjesääntö. https://www.hippos.fi/jalostus_ja_nayttelyt/ jalostusohjesaannot/jalostusohjesaanto_suomenhevosille (Breeding regulations of the Finnhorse). Visited 21.2. 2020. In Finnish.

Foll, M., \& Gaggiotti, O. E. (2008). A genome scan method to identify selected loci appropriate for both dominant and codominant markers: A Bayesian perspective. Genetics, 180(2), 977-993. https://doi. org/10.1534/genetics.108.092221

Frantz, L. A. F., Bradley, D. G., Larson, G., \& Orlando, L. (2020). Animal domestication in the era of ancient genomics. Nature Reviews Genetics, 21, 449-460. https://doi.org/10.1038/s41576-020-0225-0

Geor, R. J. (2008). Metabolic predispositions to laminitis in horses and ponies: Obesity, insulin resistance and metabolic syndromes. Journal of Equine Veterinary Science, 28(12), 753-759. https://doi. org/10.1016/j.jevs.2008.10.016

Grilz-Segera, G., Reiter, S., Neuditschko, M., Wallner, B., Rieder, S., Leeb, T., Jagannath, V., Mesarič, M., Cotman, M., Pausch, H.,
Lindgren, G., Velie, B., Horna, M., Brem, G., \& Druml, T. (2020). A genome-wide association analysis in Noriker horses identifies a SNP associated with roan coat color. Journal of Veterinary Science, 88, 102950. https://doi.org/10.1016/j.jevs.2020.102950

Gurgul, A., Jasielczuk, I., Semik-Gurgul, E., Pawlina-Tyszko, K., Stefaniuk-Szmukier, M., Szmatoła, T., Polak, G., Tomczyk-Wrona, I., \& Bugno-Poniewierska, M. (2019). A genome-wide scan for diversifying selection signatures in selected horse breeds. PLoS One, 14, e0210751. https://doi.org/10.1371/journal.pone.0210751

Haase, B., Brooks, S. A., Schlumbaum, A., Azor, P. J., Bailey, E., Alaeddine, F., Mevissen, M., Burger, D., Poncet, P.-A., Rieder, S., \& Leeb, T. (2007). Allelic heterogeneity at the equine KIT locus in dominant white horses. Plos Genetics, 3, e195. https://doi. org/10.1371/journal.pgen.0030195

Haase, B., Brooks, S. A., Tozaki, T., Burger, D., Poncet, P.-A., Rieder, S., Hasegawa, T., Penedo, C., \& Leeb, T. (2009). Seven novel KIT mutations in horses with white coat colour phenotypes. Animal Genetics, 40(5), 623-629. https://doi.org/10.1111/j.1365-2052.2009.01893.x

Hallamaa, R. E. (2009). Characteristics of equine summer eczema with emphasis on differences between Finnhorses and Icelandic horses in a 11-year study. Acta Veterinaria Scandinavica, 51, 29. https://doi. org/10.1186/1751-0147-51-29

Hauswirth, R., Haase, B., Blatter, M., Brooks, S. A., Burger, D., Drögemüller, C., Gerber, V., Henke, D., Janda, J., Jude, R., Magdesian, K. G., Matthews, J. M., Poncet, P.-A., Svansson, V., Tozaki, T., Wilkinson-White, L., Penedo, M. C. T., Rieder, S., \& Leeb, T. (2012). Mutations in MITF and PAX3 cause "Splashed White" and other white spotting phenotypes in horses. PLoS Genetics, 8, e1002653. https://doi.org/10.1371/journal.pgen.1002653

Hauswirth, R., Jude, R., Haase, B., Bellone, R. R., Archer, S., Holl, H., Brooks, S. A., Tozaki, T., Penedo, M. C. T., Rieder, S., \& Leeb, T. (2013). Novel variants in the KIT and PAX3 genes in horses with white spotted coat colour phenotypes. Animal Genetics, 44(6), 763765. https://doi.org/10.1111/age.12057

Hill, E. W., Gu, J., Eivers, S. S., Fonseca, R. G., McGivney, B. A., Govindarajan, P., Orr, N., Katz, L. M., \& MacHugh, D. (2010). A sequence polymorphism in MSTN predicts sprinting ability and racing stamina in Thoroughbred horses. PLoS One, 5, e8645. https:// doi.org/10.1371/journal.pone.0008645

Huang, D. W., Sherman, B. T., \& Lempicki, R. A. (2009). Systematic and integrative analysis of large gene lists using DAVID Bioinformatics Resources. Nature Protocols, 4, 44-57. https://doi.org/10.1038/ nprot.2008.211

Issel-Tamer, L., \& Rine, J. (1997). The evolution of mammalian olfactory receptor genes. Genetics, 145(1), 185-195.

Jäderkvist, F. K., Johansson, L., Mäenpää, M., Mykkänen, A., Andersson, L. S., Velie, B. D., Andersson, L., Árnason, T., \& Lindgren, G. (2015). Different DMRT3 genotypes are best adapted for harness racing and riding in Finnhorses. Journal of Heredity, 106(6), 734-740. https://doi.org/10.1093/jhered/esv062

Jäderkvist, K., Andersson, L. S., Johansson, A. M., Árnason, T., Mikko, S., Eriksson, S., Andersson, L., \& Lindgren, G. (2014). The DMRT3 'Gait keeper' mutation affects performance of Nordic and Standardbred trotters. Journal of Animal Science, 92(10), 42794286. https://doi.org/10.2527/jas.2014-7803

Jansen, T., Forster, P., Levine, M. A., Oelke, H., Hurles, M., Renfrew, C., Weber, J., \& Olek, K. (2002). Mitochondrial DNA and the origins of the domestic horse. Proceedings of the National Academy of Sciences of the United States of America, 16, 10905-10910. https:// doi.org/10.1073/pnas.152330099 
Jasielczuk, I., Gurgul, A., Szmatoła, T., Semik-Gurgul, E., PawlinaTyszko, K., Stefaniuk-Szmukier, M., Polak, G., Tomczyk-Wrona, I., \& Bugno-Poniewierska, M. (2020). Linkage disequilibrium, haplotype blocks and historical effective population size in Arabian horses and selected Polish native horse breeds. Livestock Science, 239, 104095. https://doi.org/10.1016/j.livsci.2020.104095

Katz, L. M., \& Bailey, S. R. (2012). A review of recent advances and current hypotheses on the pathogenesis of acute laminitis. Equine Veterinary Journal, 44(6), 752-761. https://doi. org/10.1111/j.2042-3306.2012.00664.x

Kvist, L., Niskanen, M., Mannermaa, K., Wutke, S., \& Aspi, J. (2019). Genetic variability and history of a native Finnish horse breed. Genetics Selection Evolution, 51, 35. https://doi.org/10.1186/s1271 1-019-0480-8

Librado, P., Gamba, C., Gaunitz, C., Der Sarkissian, C., Pruvost, M., Albrechtsen, A., Fages, A., Khan, N., Schubert, M., Jagannathan, V., Serres-Armero, A., Kuderna, L. F. K., Povolotskaya, I. S., SeguinOrlando, A., Lepetz, S., Neuditschko, M., Thèves, C., Alquraishi, S., Alfarhan, A. H., ... Orlando, L. (2017). Ancient genomic changes associated with domestication of the horse. Science, 356(6336), 442-445. https://doi.org/10.1126/science.aam5298

Ludwig, A., Pruvost, M., Reissmann, M., Benecke, N., Brockmann, G. A., Castanos, P., Cieslak, M., Lippold, S., Llorente, L., Malaspinas, A.-S., Slatkin, M., \& Hofreiter, M. (2009). Coat color variation at the beginning of horse domestication. Science, 324(5926), 485. https://doi.org/10.1126/science.1172750

Makvandi-Nejad, S., Hoffman, G. E., Allen, J. J., Chu, E., Gu, E., Chandler, A. M., Loredo, A. I., Bellone, R. R., Mezey, J. G., Brooks, S., \& Sutter, N. B. (2012). Four loci explain $83 \%$ of size variation in the horse. PLoS One, 7, e39929. https://doi.org/10.1371/journ al.pone.0039929

McGivney, B. A., Browne, J. A., Fonseca, R. G., Katz, L. M., Machugh, D. E., Whiston, R., \& Hill, E. W. (2012). MSTN genotypes in Thoroughbred horses influence skeletal muscle gene expression and racetrack performance. Animal Genetic, 43(6), 810-812. https://doi. org/10.1111/j.1365-2052.2012.02329.x

Metallinos, D. L., Bowling, A. T., \& Rine, J. (1998). A missense mutation in the endothelin-B receptor gene is associated with lethal white foal syndrome: An equine version of Hirschsprung disease. Mammalian Genome, 9, 426-431. https://doi.org/10.1007/s0033 59900790

Metzger, J., Schrimpf, R., Philipp, U., \& Distl, O. (2013). Expression levels of LCORL are associated with body size in horses. PLoS One, 8, e56497. https://doi.org/10.1371/journal.pone.0056497

Metzger, J., Tonda, R., Beltran, S., Agueda, L., Gut, M., \& Distl, O. (2014). Next generation sequencing gives an insight into the characteristics of highly selected breeds versus non-breed horses in the course of domestication. BMC Genomics, 15, 562. https://doi. org/10.1186/1471-2164-15-562

Mignon-Grasteau, S., Boissy, A., Bouix, J., Faure, J.-M., Fisher, A. D., Hinch, G. N., Jensen, P., Le Neindre, P., Mormède, P., Prunet, P., Vandeputte, M., \& Beaumont, C. (2005). Genetics of adaptation and domestication in livestock. Livestock Production Science, 93(1), 3-14. https://doi.org/10.1016/j.livprodsci.2004.11.001

Niimura, Y., Matsui, A., \& Touhara, K. (2014). Extreme expansion of the olfactory receptor gene repertoire in African elephants and evolutionary dynamics of orthologous gene groups in 13 placental mammals. Genome Research, 24, 1485-1496. https://doi. org/10.1101/gr.169532.113
Ojala, I. (1997). Yleishevoskantakirja, yritys suomalaisen sotilasratsun kehittämiseksi. In M. Palokangas, I. Ojala, P. Mikkola \& J. Valve (Eds.), Ratsuväen Vuosikirja II (pp. 55-65). Ratsumieskilta ry. In Finnish.

Ojala, I. (2007). Suomalainen hevonen ja suomenhevonen sotilashevosena. In M. Saastamoinen (Ed.), Suomenhevonen (pp. 17-32). Gummerus Kirjapaino Oy. In Finnish.

Ojala, M., Peltonen, T., \& Saastamoinen, M. (2007). Suomenhevosen jalostus. In M. Saastamoinen (Ed.), Suomenhevonen (pp. 127-162). Gummerus Kirjapaino Oy. In Finnish.

Orlando, L., Ginolhac, A., Zhang, G., Froese, D., Albrechtsen, A., Stiller, M., Schubert, M., Cappellini, E., Petersen, B., Moltke, I., Johnson, P. L. F., Fumagalli, M., Vilstrup, J. T., Raghavan, M., Korneliussen, T., Malaspinas, A.-S., Vogt, J., Szklarczyk, D., Kelstrup, C. D., ... Willerslev, E. (2013). Recalibrating Equus evolution using the genome sequence of an early Middle Pleistocene horse. Nature, 499, 74-78. https://doi.org/10.1038/nature12323

Peltonen, M. (2014). Kantakirjahevonen. In S. Savikko (Ed.), Suomenhevonen - arjen sankari (pp. 87-99). Amanita. In Finnish.

Perttunen, E. (2007). Suomenhevosen värit. In M. Saastamoinen (Ed.), Suomenhevonen (pp. 108-124). Gummerus Kirjapaino Oy. In Finnish.

Petersen, J. L., Mickelson, J. R., Cothran, E. G., Andersson, L. S., Axelsson, J., Bailey, E., Bannasch, D., Binns, M. M., Borges, A. S., Brama, P., da Câmara Machado, A., Distl, O., Felicetti, M., FoxClipsham, L., Graves, K. T., Guérin, G., Haase, B., Hasegawa, T., Hemmann, K., ... McCue, M. E. (2013). Genetic diversity in the modern horse illustrated from genome-wide SNP Data. PLoS One, 8, e54997. https://doi.org/10.1371/journal.pone.0054997

Petersen, J. L., Mickelson, J. R., Rendahl, A. K., Valberg, S. J., Andersson, L. S., Axelsson, J., Bailey, E., Bannasch, D., Binns, M. M., Borges, A. S., Brama, P., da Câmara Machado, A., Capomaccio, S., Cappelli, K., Cothran, E. G., Distl, O., Fox-Clipsham, L., Graves, K. T., Guérin, G., ... McCue, M. E. (2013). Genome-wide analysis reveals selection for important traits in domestic horse breeds. PLoS Genetics, 9, e1003211. https://doi.org/10.1371/journ al.pgen.1003211

Promerová, M., Andersson, L. S., Juras, R., Penedo, M. C., Reissmann, M., Tozaki, T., Bellone, R., Dunner, S., Hořín, P., Imsland, F., Imsland, P., Mikko, S., Modrý, D., Roed, K. H., Schwochow, D., Vega-Pla, J. L., Mehrabani-Yeganeh, H., Yousefi-Mashouf, N., Cothran, E. G., ... Andersson, L.(2014). Worldwide frequency distribution of the 'Gait keeper' mutation in the DMRT3 gene. Animal Genetics, 45(2), 274-282. https://doi.org/10.1111/age.12120

Purcell, S., \& Chang, C. (2018). PLINK 1.9. www.cog-genomics.org/ plink/1.9/

Purcell, S., Neale, B., Todd-Brown, K., Thomas, L., Ferreira, M. A. R., Bender, D., Maller, J., Sklar, P., de Bakker, P. I. W., Daly, M. J., \& Sham, P. C. (2007). PLINK: A toolset for whole-genome association and population-based linkage analysis. American Journal of Human Genetics, 81(3), 559-575. https://doi.org/10.1086/519795

Raudsepp, T., Finno, C. J., Bellone, R. R., \& Petersen, J. L. (2019). Ten years of the horse reference genome: Insights into equine biology, domestication and population dynamics in the post-genome era. Animal Genetics, 50(6), 569-597. https://doi.org/10.1111/age.12857

Reissman, M., Bierwolf, J., \& Brockman, G. A. (2007). Two SNPs in the SILV gene are associated with silver coat colour in ponies. Animal Genetics, 38(1), 1-6. https://doi. org/10.1111/j.1365-2052.2006.01553.x 
Schubert, M., Jónsson, H., Chang, D., Der Sarkissian, C., Ermini, L., Ginolhac, A., Albrechtsen, A., Dupanloup, I., Foucal, A., Petersen, B., Fumagalli, M., Raghavan, M., Seguin-Orlando, A., Korneliussen, T. S., Velazquez, A. M. V., Stenderup, J., Hoover, C. A., Rubin, C.-J., Alfarhan, A. H., ... Orlando, L. (2014). Prehistoric genomes reveal the genetic foundation and cost of horse domestication. Proceeding of the National Academy of Sciences of the United States of America, 52, E5661-E5669. https://doi.org/10.1073/pnas.1416991111

Shrestha, M., Eriksson, S., Schurink, A., Andersson, L. S., Sundquist, M., Frey, R., Broström, H., Bergström, T., Ducro, B., \& Lindgren, G. (2015). Genome-wide association study of insect bite hypersensitivity in Swedish-born Icelandic horses. Journal of Heredity, 106(4), 366-374. https://doi.org/10.1093/jhered/esv033

Shuai, K., \& Liu, B. (2003). Regulation of JAK-STAT signalling in the immune system. Nature Reviews Immunology, 3, 900-911. https:// doi.org/10.1038/nri1226

Signer-Hasler, H., Flury, C., Haase, B., Burger, D., Simianer, H., Leeb, T., \& Rieder, S. (2012). A genome-wide association study reveals loci influencing height and other conformation traits in horses. PLoS One, 7, e37282. https://doi.org/10.1371/journal.pone.0037282

Staiger, E. A., Almén, M. S., Promerová, M., Brooks, S., Cothran, E. G., Imsland, F., Jäderkvist, F. K., Lindgren, G., Mehrabani, Y. H., Mikko, S., Vega-Pla, J. L., Tozaki, T., Rubin, C. J., \& Andersson, L. (2017). The evolutionary history of the DMRT3 'Gait keeper' haplotype. Animal Genetics, 48(5), 551-559. https://doi.org/10.1111/age.12580

Suontama, M., Saastamoinen, M. T., \& Ojala, M. (2009). Estimates of non-genetic effects and genetic parameters for body measures and subjectively scored traits in Finnhorse trotters. Livestock Science, 124(1-3), 205-209. https://doi.org/10.1016/j.livsci.2009.01.017

Suontama, M., van der Werf, J. H., Juga, J., \& Ojala, M. (2013). Genetic correlations for foal and studbook traits with racing traits and implications for selection strategies in the Finnhorse and Standardbred trotter. Journal of Animal Breeding and Genetics, 130(3), 178-189. https://doi.org/10.1111/j.1439-0388.2012.01011.x

Takahashi, A., Kosugi, T., Kobayashi, Y., Yamanome, T., Schiöth, H. B., \& Kawauchi, H. (2007). The melanin-concentrating hormone receptor 2 (MCH-R2) mediates the effect of $\mathrm{MCH}$ to control body color for background adaptation in the barfin flounder. General and Comparative Endocrinology, 151(2), 210-219. https://doi. org/10.1016/j.ygcen.2007.01.011

Tetens, J., Widmann, P., Kühn, C., \& Thaller, G. (2013). A genome-wide association study indicates LCORL/NCAPG as a candidate locus for withers height in German Warmblood horses. Animal Genetics, 44(4), 467-471. https://doi.org/10.1111/age.12031

Thiruvendakan, A. K., Kandasamy, N., \& Panneerselvam, S. (2008). Coat colour inheritance in horses. Livestock Science, 117(2-3), 109-129. https://doi.org/10.1016/j.livsci.2008.05.008
Velie, B. D., Bas, C. L., Petäjistö, K., Røed, K. H., Ihler, C. F., Strand, E., Fegraeus, K. J., \& Lindgren, G. (2018). The importance of MSTN for harness racing performance in the Norwegian-Swedish Coldblooded Trotter and the Finnhorse. Proceedings of the World Congress on Genetics Applied to Livestock Production, 11, 36.

Velie, B. D., Lillie, M., Fegraeus, K. J., Rosengren, M. K., Solé, M., Wiklund, M., Ihler, C.-F., Strand, E., \& Lindgren, G. (2019). Exploring the genetics of trotting racing ability in horses using a unique Nordic horse model. BMC Genomics, 20, 104. https://doi. org/10.1186/s12864-019-5484-9

Vychodilova, L., Matiasovic, J., Bobrova, O., Futas, J., Klumplerova, M., Stejskalova, K., Cvanova, M., Janova, E., Osickova, J., Vyskocil, M., Sedlinska, M., Dusek, L., Marti, E., \& Horin, P. (2013). Immunogenomic analysis of insect bite hypersensitivity in a model horse population. Veterinary Immunology and Immunopathology, 152(3-4), 260-268. https://doi.org/10.1016/j.vetimm.2012.12.013

Wagner, B. (2015). Immunoglobulin E and allergy. Equine Veterinary Journal, 48(1), 13-14. https://doi.org/10.1111/evj.12513

Wilkins, A. S., Wrangham, R. W., \& Fitch, T. (2014). The domestication syndrome in mammals: Unified explanation based on neural crest cell behavior and genetics. Genetics, 197(3), 795-808. https://doi. org/10.1534/genetics.114.165423

Wilson, A. D., Harwood, L., Torsteinsdottir, S., \& Marti, E. (2006). Production of monoclonal antibodies specific for native equine $\operatorname{IgE}$ and their application to monitor total serum $\operatorname{IgE}$ responses in Icelandic and non-Icelandic horses with insect bite dermal hypersensitivity. Veterinary Immunology and Immunopathology, 112(34), 156-170. https://doi.org/10.1016/j.vetimm.2006.02.003

Wutke, S., Andersson, L., Benecke, N., Sandoval-Castellanos, E., Gonzalez, J., Hallsteinn, H. J., Lõugas, L., Magnell, O., MoralesMuniz, A., Orlando, L., Pálsdóttir, A. H., Reissmann, M., MuñozRodríguez, M. B., Ruttkay, M., Trinks, A., Hofreiter, M., \& Ludwig, A. (2015). The origin of ambling horses. Current Biology, 26(15), R697-R699. https://doi.org/10.1016/j.cub.2016.07.001

\section{SUPPORTING INFORMATION}

Additional supporting information may be found online in the Supporting Information section.

How to cite this article: Kvist L, Honka J, Niskanen M, Liedes O, Aspi J. Selection in the Finnhorse, a native all-around horse breed. J Anim Breed Genet. 2021;138:188-203. https://doi.org/10.1111/jbg.12524 